\title{
The Development of Mathematical Innovation Ability Based on Empirical Analysis
}

\author{
Hongmei Nie \\ Math, Physics and Information Engineering College, Zhejiang Normal University \\ Jinhua, China \\ e-mail:nhm@zjnu.cn
}

\begin{abstract}
The education ministry explicitly has pointed out that we must push forward overall quality education and improve national innovation ability. Mathematics education is a part of education system, so the cultivation and development of mathematics innovation ability as an important subject of national quality education, this is beneficial to cultivate a new generation of innovative talents. First, the paper discusses the teaching connotation of the new course standard, and furthermore, referencing the new course standard connotation, summarizes the main ideas of developing mathematics innovative ability. Secondly, referencing the theory of the new course standard and the main ideas of developing mathematics innovation ability, the paper put forward evaluation indexes, and collects the relevant data by interview and questionnaire. Finally, for the random effect model, the paper carries on systematic analysis and research. Therefore, for the summarized main ideas about the cultivation and development of mathematics innovation ability, this paper provides an empirical basis.
\end{abstract}

Keywords-new course standard; mathematics innovation ability; evaluation index; empirical analysis

\section{INTRODUCTION}

With the accelerating of internationalization pace, countries around the world generally have realized the importance of training creative and applied talents. So the focus of education reform is turned to the cultivation of students' creativity and application ability. How to cultivate students' creativity and application ability has become one of the focuses of education reform. Foreign many educators, scholars and teachers have constantly committed to the research and practice of this field, and made some achievements[1][2][3].

At present, our country is carrying on the new basic education curriculum reform. One of the goals of the reform is to change the current situation of the passive learning and mechanical training, and encourage students' active, exploring, and diligent spirit. Especially the reform emphasizes that teaching process is the interactive process of communication and common development between teachers and students. In teaching, teachers should pay attention to cultivate students' independence and autonomy, and guide students to query, investigate, and research. Teachers should respect students' personality, pay attention to individual differences, create the teaching environment for students to actively participate in, inspire students' learning enthusiasm, and cultivate the ability to students to master and apply knowledge, so that every student can be fully developed[4][5].

The education ministry explicitly has pointed out that we must push forward overall quality education and improve national innovation ability[6].The talents that we cultivate in the new century should possess higher mathematical literacy. Mathematics innovation ability is an important part of mathematical literacy; therefore, developing mathematics innovation ability has become one of the most important goals of current education.

Reviewing the changes of the mathematics education in our country, we know that our country has always attached great importance to the cultivation and development of mathematics innovation ability. For example, in 2002, the revised syllabus and the comprehensive reform of teaching materials have reflected the degree of attention of cultivating mathematics innovation ability. However, in the past ten years, due to the examination, graduation rates and other factors, whether teachers or students paid more attention to pure mathematical calculation, ignoring the development of mathematics innovation ability, which led to the university students' mathematics innovation ability is generally poor.

In recent years, many experts and scholars have increasingly perfected the study on the development of mathematics innovation ability. On the basis of the previous study, and referencing the theory of the new course standard, the paper summarizes the main ideas of the development of mathematics innovation ability. Then, referencing the theory of the new course standard and the main ideas of developing mathematics innovation ability collects the relevant data by interview and questionnaire. Finally, selecting the students' mathematics innovation achievement as the dependent variable, all the evaluation indexes as the predictors, using the random effect model, analyzes the relationship between the dependent variable and the predictors. Thus, for the summarized main ideas about the cultivation and envelopment of mathematics innovation ability, this paper provides an empirical basis.

\section{The Teaching Connotation Under The NeW Course STANDARD}

At present, the demands for talents are various, so we should cultivate various types of talents to adapt to social development. Therefore, the "one-size-fits-all" traditional 
education model has not met the needs of modern education, more not adapted to the needs of social progress. With the implementation of the teaching reform, the basic value orientation under the new course standard is to develop each student, which is the soul of the teaching reform. In other words, that is to cultivate students' independence, autonomy and creativity, and make every student's individuality fully developed. In the process of actual teaching, teachers unilaterally emphasis on instilling knowledge and skills, ignore the development of students' individuality. Teaching materials as a god, teachers and students passively teach and learn, being lack of necessary flexibility and creativity. In class, students mechanically learn, being lack of autonomy and subjectivity. Teaching evaluation is single, ignoring the process evaluation and the expansibility, diversity and individuality of evaluation. Therefore, under the new course standard, according to our own professional knowledge, students' individuality, teaching equipment, teaching materials, etc., we should properly choose teaching method, and let all kinds of teaching methods achieve mutual coordination, further improving the teaching quality[4][5][7].

\section{A. Create a harmonious teaching environment}

Successful teaching relies on the respect and trust of the relationship between teachers and students, relies on a harmonious and safe classroom environment. Teachers should be easy to get along with students, and truly become the mentors of students. In teaching, teachers have not the only answer; every student has his own understanding. Even if students have a lot of views and opinions, their views and opinions also can be regard as right answers. Only by creating such a relaxed and harmonious environment, students' individualized development can grow in the right soil. Only with teachers' democracy, equality, and respect, students' learning enthusiasm can be inspired, students' innovation can be sparked, thus the goal of training students can be realized[4] [7].

\section{B. Change the way of reading materials}

Usually, according to the teaching materials' order, we step by step learn. In accordance with the new course standard, first teachers should individually understand and read the materials. By the needs of students, teachers should give full play to own creativity, establishing, organizing and integrating teaching materials system. This is the basis of cultivating creative and applied talents[7].

\section{Enrich teaching design}

Teaching is a science, is also an art. Teaching design is a dynamic and an opening process. On the basis of accurately reading teaching materials, teachers should advance with the times and creatively think, so that further enrich teaching design. Teachers should set up multiple learning goals and a variety of teaching methods, making every student according to own actual need choose the appropriate content to learn[8].Teachers should provide broad independent exploration space for students, stimulating the creative thinking, encouraging a variety of methods of solving problem. The purpose of teaching design is to make every student's individuality fully developed [7].

\section{Enrich teaching language}

The individualized teaching language is the external manifestation of a teacher's teaching style. It is a key that can induce students' thought, inspire students' innovation enthusiasm, and improve the teaching quality. In teaching, teachers' language should not be the pure megaphone of knowledge, but should be impassioned, accurate, logical, humor, or interesting. No matter what kind of form, the purpose of teachers' language is to attract and infect students[7][9].

\section{E. Diversify teaching evaluation}

The traditional teaching evaluation puts more emphasis on the results instead of on the process. The traditional evaluation is one-sided and narrow, which shows basically that the examinations decide everything. However, we know that there are individual differences between students. So we can't use a ruler to measure all of the students. Otherwise, the students that we cultivate are the unified products. Intellectual, social, emotional, and physical aspects being different leads to the differences between students, thus we must take the development view to make a comprehensive and objective evaluation for students, as far as possible finding the student's advantage. For example, for students with excellent grades, teachers should more strictly prompt them to achieve a higher goal, and constantly surpass themselves. For ordinary students, based on the fully affirmed achievements, teachers should point out the direction for them, and enhance their learning and exploring enthusiasm. For students with poor grades, teachers should not tease and ridicule them, but patiently help them, encourage students to make progress all the time, and fully mobilize students' desire to do better[7][10].

\section{THE MAIN IDEAS OF DEVELOPING MATHEMATICS INNOVATION ABILITY}

The new course standard points out that cultivating students' innovation consciousness and practical ability is one of the important goals of teaching reform. Therefore, we must pay much attention to the development of mathematics innovation ability.

The author believes that we must possess all kinds of ability in order to achieve an innovation achievement. So, mathematics innovation ability is the comprehensive expression of one's perseverance, wisdom, skill, personality, and creative ability. In order to obtain an innovation achievement, first of all, we must have advanced innovation consciousness. Because of possessing the consciousness, we really have the motivation of an innovation. However, perseverance is the necessary condition to realize an innovative achievement. If we put aside this condition, the innovative consciousness became a piece of blank paper. However, the people who work do not always get fruitful results. Only when a person has a profound, broad, agile, creative, and critical thinking, in the end, he will achieve an innovation achievement Therefore, the author thinks that the innovation ability consists 
of three basic elements of innovation consciousness, innovation spirit and innovation thinking.

Innovative consciousness is the premise and key of innovation ability. With innovative consciousness, we can create opportunities, methods and thinking to obtain innovation achievement.

Innovative spirit is the lofty ideal and pursuit, and is the hardworking and strong style.

Innovative thinking is the core content of innovation ability. The essence of innovative thinking is a manifestation that reflects comprehensively agile, profound, flexible, individualized, broad, and critical thinking.

In order to obtain mathematics innovation achievement, we must cultivate and develop mathematics innovation ability. Therefore, we must carry on mathematics teaching reform. By referencing to the theory of the new course standard, the author summarizes the main aspects of mathematics teaching reform for your reference:

\section{A. The reform of teaching materials}

We should choose those teaching materials that can be widely applied to the modern social life and production practice. At the same time, we should create experimental teaching materials and research project. By establishing, organizing and integrating teaching materials system, we can provide an opportunity for innovative consciousness and practice ability[7][11].

\section{B. The reform of teaching methods}

Teachers must change the pure way of instilling into knowledge to students. Teaching process is the interactive process of the communication between teachers and students. Therefore, in the teaching, teachers should stimulate students' curiosity about mathematics, cultivate students' ability of independent thinking and solving problem, and inspire students' innovation enthusiasm[7][12].

\section{The reform of learning methods}

Teachers should help students to master the scientific learning method, and form active learning attitude[7].

\section{The reform of teaching tools}

We should vigorously promote information technology to be widely applied in teaching process, and give full play to the advantages of information technology, to provide powerful tools for students' learning and development[13].

\section{E. The reform of teaching evaluation}

Evaluation is not an end, but a starting point motivating students' better development. Mainly according to the ability to obtain knowledge, the ability to find problems and solve problem three aspects, we set evaluation index system[7][10].

\section{THE EMPIRICAL ANALYSIS}

\section{A. Put forward the evaluation indexes}

The new course standard point out that teaching process is an interaction process between teachers and students. Therefore both teaching and learning should be brought into the teaching evaluation field.

Based on the above reasons, and by referencing the theory of the new course standard and the main ideas of developing mathematics innovation ability, the paper establishes an evaluation table 1 . Collect data and set variables

\section{1) Collect data}

The author randomly selects 50 students and 3 teachers of mathematics as the objects of investigation from our school.

TABLE I. THE EVALUATION INDEXES

\begin{tabular}{|c|c|}
\hline Evaluation indexes & score \\
\hline Learning attitude & 100 \\
\hline Cooperation level & 100 \\
\hline Memory ability & 100 \\
\hline Modesty degree & 100 \\
\hline Study habit & 100 \\
\hline Innovation ability & 100 \\
\hline Expression ability & 100 \\
\hline Calculative ability & 100 \\
\hline Individualized mathematics teaching & 100 \\
\hline
\end{tabular}

\section{2) Set variables}

The paper sets the students' mathematics innovation achievement as a dependent variable. Meanwhile, sets the learning attitude, cooperation level, memory ability, modesty degree, study habits, innovation ability, expression ability, calculative ability and individualized mathematics teaching as independent predictors.

For the convenience of calculating, Lets $y$ be the dependent variable, and lets $x_{1}, x_{2}, \ldots, x_{m}$ respectively be the independent predictors.

\section{B. Process and analyze data}

By processing the data, we get correlation analyses results. Table 2 and table 3 show the correlation analysis results.

Table 2 shows the significance test result of the regression equation. For Sig. in the anova table being less than $0.05(\alpha=0.05)$, so the regression equation is significant.

Table 3 shows the test results of the regression constants and regression coefficients. For Sig. in the Coefficients table being less than $0.05(\alpha=0.05)$, so the influence of the predictors $x_{6}, x_{9}$ on the dependent variable $y$ is significant. Therefore, the linear regression equation is 


$$
y=19.026+4.424 x_{6}+3.586 x_{9} .
$$

The above analysis results show that the relationship of mathematics innovation achievement with two indexes (innovation ability and individualized mathematics teaching) is a linear relationship.

TABLE II.

$\operatorname{ANOVA}(\mathrm{C})$

\begin{tabular}{|c|c|c|c|c|c|c|}
\hline Model & & Sum of Squares & df & Mean Square & $\mathbf{F}$ & Sig. \\
\hline \multirow[t]{3}{*}{1} & Regression & 4812.162 & 1 & 4812.162 & 476.434 & $.000(a)$ \\
\hline & Residual & 484.818 & 48 & 10.100 & & \\
\hline & Total & 5296.980 & 49 & & & \\
\hline \multirow[t]{3}{*}{2} & Regression & 5044.703 & 2 & 2522.351 & 469.922 & $.000(b)$ \\
\hline & Residual & 252.277 & 47 & 5.368 & & \\
\hline & Total & 5296.980 & 49 & & & \\
\hline
\end{tabular}

TABLE III. COEFFICIENTS(A)

\begin{tabular}{|c|c|c|c|c|c|c|}
\hline Model & & \multicolumn{2}{|c|}{$\begin{array}{c}\text { Unstandardized } \\
\text { Coefficients }\end{array}$} & $\begin{array}{c}\text { Standardized } \\
\text { Coefficients }\end{array}$ & $\mathbf{t}$ & Sig. \\
\hline & & $\boldsymbol{B}$ & Std. Error & Beta & & \\
\hline 1 & (Constant) & 12.978 & 2.921 & & 4.443 & .000 \\
& $\mathrm{X} 1$ & 7.995 & .366 & .953 & 21.827 & .000 \\
2 & (Constant) & 19.026 & 2.319 & & 8.203 & .000 \\
& $\mathrm{X} 6$ & 4.424 & .605 & .527 & 7.316 & .000 \\
& $\mathrm{X} 9$ & 3.586 & .545 & .475 & 6.582 & .000 \\
\hline
\end{tabular}

a Dependent Variable: $\mathrm{Y}$

\section{Make the conclusion of the analysis}

Through the above analysis, we get the following conclusions. Mathematics innovation achievement is mainly affected by two factors which are individualized mathematics teaching and the innovation ability of students. Therefore, for innovative achievements, the cultivation and development of the innovative ability of students plays a vital role.

Only by practical teaching activities, we can cultivate and develop mathematics innovation ability, so we need to reform each key link of practical teaching activities. Namely, for each teaching link, such as teaching materials, teaching methods, learning methods, teaching tools, teaching evaluation, etc. we must carry on a comprehensive reform and innovation. Only in this way, we can achieve the cultivation and development of mathematics innovation ability, offering innovative talents for the country.

\section{CONCLUSION}

By referencing the new course standard connotation, the paper summarizes the main ideas of developing mathematics innovative ability. Then, using the random effect model, the paper provides an empirical basis for the summaried main ideas.

A teaching effect model involves education, statistics, computer intelligence technology, and many other course of knowledge, so we have to study a lot of knowledge. Although spending a great deal of effort, but since time is limited, the author studies the effect model only based on part of the factors. So the follow-up work also need to more factors for further study. On the basis of experimental study, we need to gradually perfect the model, making it provide strong empirical basis for the cultivation and development of mathematics innovation ability.

\section{REFERENCES}

[1] Wenxia Guo. Review the current Japanese education course reform[J].Comparative Education Research, 2001(8),pp.48-52.

[2] Jianlu Chen. Germany basic education enlightenment on education in our country[J]. contemporary educational science, 2007(5-6),pp.125-126.

[3] Yongming Han,In the 21st century French education reform and its implications[J]. Comparative Education Study, 2011,pp.119-120.

[4] Tianbao Zhang,The New Curriculum and Classroom Teaching Reform[M]. Beijing: People's Education Press,2003.pp.41-126.

[5] Elementary education reform research team, Hui Zhang.The new curriculum teaching reform[M]. Capital Normal University Press,2001,pp.58-65.

[6] Ministry of Education. Facing 21st century education revitalization plan of action[p]. China Youth News,pp.1999.2.25.

[7] Elementary education reform research team, Hui Zhang.The new curriculum teaching reform[M]. Capital Normal University Press,2001,pp.66-74.

[8] Defang Sun. The selectivity research of classroom learning[M]. Guangxi University Press, pp.2011,1-3.

[9] Aixian Zhan. Rich teaching language enhance mathematics classroom teaching effect $[\mathrm{J}]$. Mathematics Learning and Research, 2014,(10),pp.132-133. 
[10] Chunlong Zhao.Classroom teaching theory and practice research[M]. Hunan University Press, 2012,pp.23-29.

[11] Daqian Li,Quality education and mathematics teaching reform[J]. China University Teaching ,2000,pp.9-10.
[12] Daqian Li. Discussion of university mathematics teaching goal and method[J]. China University Teaching,2009,pp.7-10.

[13] Xunhua Sun,Wenbiao Xie. The significance of mathematical techniques to education and teaching in the new Century[J]. Journal of Mathematics Education,2001,pp.68-70. 